\title{
More Legal Pitfalls that Startups Should Avoid
}

\author{
Paul Swegle (Seattle University School of Law)
}

KEYWORDS: Entrepreneurship, Legal, Startups.

This is Part 2 of Legal Pitfalls to Avoid in Founding a Startup, where we continue our discussion of common legal, regulatory, and fundraising mistakes that derail even the most promising startups. Here is a link to Part 1(https://eiexchange.com/content/seven-legal-pitfallsyour-startup-should-avoid?search=Swegle) .

Part 1 focused on issues startups face around the time of formation. Part 2 looks at issues up-and-running businesses should consider in hiring and managing employees, raising funds, and entering into commercial agreements.

\section{Employment Law Violations}

Employment law issues bedevil virtually all startups. This is due to a combination of factors, including the complex and ever-changing nature of these state, federal, and local employment laws, lack of sophistication, lack of resources for professional support, and financial pressures to cut corners. Here are some key mistakes to avoid:

\section{Culture and Conduct Issues}

Do not allow sexual harassment or discrimination of any kind in or around the workplace. Avoiding harassment and discrimination claims requires zero tolerance for offcolor jokes, sexual innuendo, flirtatious banter, offensive language, or jokes or discussions that could offend virtually anyone. Credible and non-credible claims alike often result in cash settlements, as the costs of litigation are simply too high.

Zero tolerance requires promptly removing offenders and making sure team members understand that policy. Founders and senior team members need to set the example that it is possible to have a fun workplace without making anyone uncomfortable.

\section{Wage and Hour Compliance}

Do not fail to pay employees for hours worked or bonuses earned, and always pay at least minimum wage. Contrary to what some think, no part of an employee's minimum wage can be paid in stock or options. Minimum wages must be paid in cash.

Wage and hour laws also require overtime pay for nonexempt workers and compliance with applicable employee break periods.

It is cleanest to prohibit overtime work by non-exempt employees and to mandate that they take their legally required breaks and to ensure that managers are aware of the importance of not trying to skirt these policies by requiring exempt employees to work odd hours.

\section{Managing Paid Time Off Liabilities}

Use care to cap exposure to accrued PTO liabilities. California law, for example, requires that all accrued PTO be paid out at termination but it does not require offering PTO or restrict caps on PTO accruals. State PTO laws are constantly changing, but most states likely allow capping PTO accruals to 40 hours total and limiting annual rollovers to 40 hours. Establish cap and rollover policies from the start to avoid problems with unexpected liabilities.

\section{Wage Theft}

When employees depart, do not fail to timely pay any final wages due, including accurately paying out any accrued PTO.

State agencies will aggressively pursue all forms of "wage theff" on behalf of workers against a startup or, as necessary, its officers and directors. In doing so, regulators will also interpret any bonus plan ambiguities in favor of employees and against a company and its officers.

I know of at least two founders being sued personally by state regulators for more than $\$ 300 \mathrm{~K}$ each, several years after their startups failed. Do not count on hiding behind a plea of poverty if your startup fails. State regulators will not take into account your inability to pay in pursuing and maintaining these claims on behalf of harmed employees. 


\section{FMLA and ADA}

Understand and comply with federal, state, and local requirements under the Family Medical Leave Act (FMLA) and the Americans with Disabilities Act (ADA). "Measure twice and cut once," as carpenters say. Responding improperly to FMLA requests for time off or to ADA requests for "reasonable accommodations" can stir up persistent, expensive legal issues. Consult experienced counsel when FMLA or ADA issues arise.

Retaining a Professional Employer Organization (PEO) once a company has 40 or more employees is another way for companies to pre-pay for guidance on these inevitable issues. PEOs enable you to outsource virtually all aspects of employee onboarding and training, payroll, leave, and benefits administration, and compliance with wage and hour and FMLA leave requirements.

\section{Employee Misclassification}

Know the distinctions between employees and independent contractors in each state where you operate. In states adopting versions of the "ABC Test," it may be virtually impossible to use individual independent contractors to fill roles that are within the "ordinary scope" of your business. If you develop software, for example, it may be difficult to hire individuals as independent contractors to write software code.

While you might get away with relying on independent contractors for several years, you might also just be accruing a huge payroll tax liability. States aggressively collect unpaid taxes. In the event of insolvency, they collect those unpaid taxes directly from company officers and board members.

\section{Performance Evaluation Documentation}

Use regular written performance reviews to help employees understand their strengths and weaknesses and improve in their roles, and use written "progressive discipline" consistently and fairly to correct poor performance or misconduct and to remove poor performers in a timely manner.

In the HR context, progressive discipline refers to any series of signed documents between an employee and employer relating to any required performance or behavioral improvements that follow an escalation pattern along these lines:
- Required performance improvements might be noted first somewhat gently in a half-yearly performance evaluation.

- Continuing performance deficiencies might be called out more extensively in an annual performance evaluation.

- Absent improvement, the deficiencies might be the subject of a more severe document, such as a "performance improvement plan" or "final warning."

PIPs and final warnings often include statements along the lines of "You have thirty days to meet the performance obligations outlined above. Failure to do so will result in discipline, including potential termination of employment."

Performance evaluations should be focused primarily on helping employees grow and succeed in their roles. Progressive discipline is focused on fixing specific problems. It also creates a written record that a company has done a reasonable job of identifying performance weaknesses, providing the employee opportunities to improve, and then giving the employee a final chance to turn things around before being fired.

While certainly not necessary under "at-will" employment, such a record helps to undercut false claims that an employee's discipline or termination was for improper purposes, such as discrimination or any form of illegal retaliation.

Consistently using thoughtful written progressive discipline in appropriate situations helps companies allows companies to terminate problem employees with less fear of expensive, unwarranted claims.

\section{Terminations}

Progressive discipline may lead to termination, but progressive discipline is not required or appropriate in all situations. A single episode of employee misconduct that violates an important company rule or policy can warrant immediate termination.

The ability to immediately terminate employees for significant misconduct is a key reason companies should adopt comprehensive company policies early, including anti-harassment and anti-discrimination policies, ethics policies, and travel and expense policies, just to name a few. Policies provide established benchmarks for assessing misconduct and appropriate 
consequences.

Follow through immediately on any decision to terminate. Delaying a well-supported termination by days or even hours can result in severe complications. Delays create opportunities for a problem employee to raise spurious claims, giving any subsequent termination the appearance of retaliation - a claim in its own right.

Employees who suspect they are about to be terminated often consult counsel and can quickly turn the tables on hesitant mangers by raising false claims. This sequence leads to greatly escalated costs and uncertainty, not to mention the risk that a now overtly hostile, poor performer will remain on the team indefinitely, given that termination will almost certainly trigger a retaliation claim.

\section{Errant Bonuses}

Never pay bonuses to underperforming employees. An errantly paid bonus can be mischaracterized as evidence of an employee's strong performance and, hence, that their termination was for a prohibited purpose, such as discrimination or retaliation.

\section{Labor Laws}

Do not trip over what are often referred to as labor laws - meaning laws allowing for union organizing or what is known as "protected, concerted activities." In addition to being allowed to organize, for example, employees are allowed to complain about their employers, including, unfortunately, on social media. They are also allowed to compare wages and benefits with impunity.

These activities can test the composure and thoughtfulness of any management team. But attempting to prohibit such activities, or retaliating against them, can result in painful regulatory consequences. It is difficult to navigate labor law issues without qualified legal counsel. Emotional and instinctual responses to labor law issues usually backfire badly.

Treat your employees well and communicate regularly with them to prevent such issues before they start. And again, promptly terminate poorly performing employees. They have the least to lose and the most to gain from engaging in antagonistic activities.

\section{Fundraising Missteps}

In Startup Law and Fundraising for Entrepreneurs and
Startup

Advisors

(https://www.amazon.com/dp/0578236702) , I spend five chapters on how to raise the right amounts of money, at the right intervals, on the right terms, and from the right investors. Here is a brief overview of some key mistakes to avoid:

\section{Premature Fundraising}

Avoid raising money from third parties until you have exhausted your personal "bootstrapping" resources to (i) assess product-market fit, (ii) design a prototype or some "vaporware," (iii) achieve minimum basic milestones, and (iv) otherwise demonstrate your startup's market opportunity and value.

In short, if you have to put $\$ 10,000$ on credit cards to avoid giving up $20 \%$ of your company for $\$ 50,000$, it is usually wise to do so.

\section{Onerous Terms}

Avoid offering terms to early investors that will turn off later investors. This means sticking to basic, commonly accepted instruments and terms - nothing exotic and nothing excessive. Convertible notes and SAFEs (Simple Agreement for Future Equity) with garden variety terms, or even Common Stock, can help keep you out of trouble. Avoid issuing preferred stock or warrants in a company's earliest financings.

Terms in early-stage financings that can cause problems later include excessive (greater than 1X) liquidation preferences, non-dilutable equity interests, pre-emptive rights to participate pro rata in future financings, and warrant coverage. Early-stage financings should be simple, simple, simple.

\section{Valuation Cap Issues}

A common problem with convertible notes and SAFEs recently has been extremely low "valuation caps." I discourage my companies from signing notes or SAFEs with valuation caps lower than $\$ 8$ million. Without delving into all of the complexities, low valuation caps create situations where future investors are unwilling to invest because earlier investors with low valuation caps will come into their same deal and receive a price per share that is $30 \%, 40 \%$ or even $50 \%$ less than what the new investors are paying. Nobody wants to look like a sucker, and future investors may simply pass when earlier investors' valuation caps are too low.

\section{Short Maturities}


Short maturity periods are another common convertible note concern. Avoid terms shorter than 24 months if possible. It frequently takes companies up to 24 months after a seed or pre-seed round to close a "qualified financing" that will automatically convert any convertible notes into shares of stock under the terms of the note. Signing convertible notes with shorter than 24-month maturity dates simply sets up a company for awkward maturity date extension negotiations, potentially resulting in a higher interest rate, lower valuation cap, or warrants.

\section{Warrants}

No early-stage company should issue warrants. Warrants raise complex accounting and administrative challenges and can be a red flag to future smart-money investors. Be wary of any early-stage investor, including an angel investor group, pushing for warrants. It is better to accept a slightly lower valuation than to issue warrants in an early financing.

\section{Founder Stock Sales}

Founders should avoid selling their own company stock to meet personal financial needs, and certainly not without board approval and advice of counsel. Founder stock sales are a red flag that can complicate or even block future fundraising efforts. They raise a host of awkward questions:

- Was the sale compliant with state and federal securities laws?

- Why is the founder dumping shares in his or her own startup?

- Why is the founder diverting the company's "corporate opportunity" to raise cash with a share offering of its own?

- Did the sale violate any contractual "Rights of First Refusal" in a shareholder agreement or elsewhere?

- What will future investors think of having those specific purchasers on the cap table?

\section{Misguided and Mismanaged Commercial Agreements}
A final genre of common startup mistakes involves contracts.

For more on each of these issues and for lots of other advice on negotiating contracts, see my book, Contract Drafting and Negotiation for Entrepreneurs and

\section{Business}

Professionals (https://www.amazon.com/dp/0692138307), but here are some of the most common mistakes to avoid.

\section{Starting Work without a Contract}

Starting work before a contract is signed almost always changes the parties' relative negotiating positions and usually results in someone getting the short end of the stick.

Business persons sometimes do this out of impatience and a belief that the company can just "walk away" if things do not work out. But walking away from an unpapered relationship can involve more than just walking away from sunk costs and delayed opportunities. The other party might have valid claims for additional compensation, often under fancy sounding legal theories couched in terms such as detrimental reliance ("I relied on your promises to my detriment") or quantum meruit ("I am owed the value of my work performed or created").

Other risks of starting work before a contract is signed involve intellectual property (IP) rights. Absent a written agreement that says otherwise, the creator of any work product is generally also its owner, including inventions and copyrightable works. To avoid unpleasant surprises, negotiate IP ownership terms upfront, not after the work has been done.

\section{Unclear Obligations}

In negotiating any contract, make sure each party's obligations are crystal clear. Deliverables of all types must be well-defined, including project scope, completion timelines, functional requirements, technical specifications, integration support and testing, and procedures for acceptance or rejection of contract deliverables.

Never assume that the other side will perform beyond what a contract specifically requires, or that the parties will amicably work through any gaps or ambiguities. On the contrary, always assume that unclear or ambiguous terms will result in significant disappointments. Pushing for clarity and specificity can be awkward and stressful, but I usually recommend just blaming "the lawyers."

\section{Flawed Technical Specifications}

The accuracy of technical specifications is paramount. If you ask a vendor to build something based on incorrect specifications that you provided, you will be stuck with 
the resulting defective work product and all problems that flow from those defects.

I once had to support a health device recall ordered by the FTC when a manufacturer faithfully produced tens of thousands of devices according to flawed sensor specifications. Not only did the startup that provided the flawed specifications lose all of its device revenues and incur almost $\$ 1 \mathrm{M}$ of regulatory and recall-related expenses, but it still owed the manufacturer $\$ 1.2$ million for creating the defective products. This single error destroyed the company, along with its promising idea and about 200 jobs.

\section{Poorly Defined IP Rights}

Almost every type of commercial agreement implicates IP rights in one way or another. Any time IP will be created, negotiate who will own it. Any time one party will use another party's IP, make sure the details of those uses are clear.

As a general rule, purchasers of development services should want to own everything they are buying and should insist on broad language in "Master Services Agreements" and similar documents making all deliverables "works made for hire" and assigning all invention rights to the purchaser.

Conversely, sellers of development services may want to retain portions of certain "pre-existing" IP embedded in deliverables and will insist on binding purchasers to licenses defining the purchasers' rights to that IP, particularly if the seller intends to sell those IP components again in connection with other development projects.

These competing IP interests require thoughtful and determined negotiation, particularly on the part of companies purchasing development services. Purchasers should be leery of contracts that might later raise doubts about the ownership and transferability of critical IP.

\section{Weak Remedies}

Negotiating clear rights and obligations in a contract is just half the battle. The other half involves negotiating reasonable remedies in case a party does not perform or makes costly mistakes. Always insist on a right to terminate an agreement if the other party is in breach.

In negotiating these rights, a purchaser should focus on "rights to cure" any breaches and seek to limit those rights. I often add a clause that says essentially, "The non-breaching party shall have an immediate right to terminate in the event the other party has already exercised rights to cure under this section on two or more occasions." Terminating an agreement with a nonperforming party can be difficult if rights to cure are not specifically limited.

Limitations of damages clauses are also frequently skewed against purchasers. It is generally insufficient to merely have a refund right in the event a purchased product or service causes your company or its customers substantial harms and losses. Clauses waiving and limiting damages should be eyed closely. Sellers of goods and services should remain liable for direct costs and losses resulting from flawed, defective, or infringing goods and services, and they should have insurance backing up those obligations.

Similarly, sellers of goods and services should agree to "indemnify and hold harmless" purchasers from third party claims of harms or losses relating to those goods and services.

Again, these are insurable obligations. Sellers of goods and services who admit to having insufficient or nonexistent insurance to cover such claims should be avoided, as should sellers who inflexibly insist on shifting risks of loss for their errors and omissions to the purchasers of their products and services.

\section{Contract Mismanagement}

Once a contract has been signed, it often goes into an implementation phase, and then into a longer managementphase. In the near term, the parties may need to meet and coordinate to ensure they are each providing any required coordination and cooperation.

From the outset, each party needs to hold the other party accountable for their respective performance obligations. When contract performance is allowed to drift by one or both parties, this provides opportunities for a non-performing party to point fingers back at the other, claiming its non-performance was waived by, or even caused by, the other party.

Because of this risk, it is important for supervisors to require regular status reports from team members overseeing a contract's execution and to ensure that performance obligations remain on track. 
As noted, commercial agreements often contain a process for a purchaser to review and test deliverables and to either accept or reject them within a stated timeframe. Be mindful of these provisions and follow them. Otherwise, a party's non-conforming deliverables may be deemed accepted under the agreement.

In managing contracts, it is important to track and anticipate automatic term (duration) renewals. Many contracts "auto-renew" annually or on some other cycle, unless one of the parties provides timely notice of nonrenewal to the other party. Notice of non-renewal often must be given at least thirty days before the renewal date, but sixty and ninety-day notice periods are also common.

Allowing disadvantageous contracts toaccidentallyautorenew is one of the most common contract blunders. Dozens of times in my career I have had to explain to panicked, disbelieving clients and colleagues that there is no way out of an unwanted contract that has just autorenewed.

Absent a goodwill gesture by the other party or ongoing breaches by them, if you miss a non-renewal notice deadline by even a single day, you are stuck for another year. Or, as in the case of one company I know that desperately wanted out of a long-term worker uniform contract, another five years.

\section{Summary}

Being aware of common mistakes does not necessarily mean you have all of the answers for avoiding or addressing them. But awareness buys you time to pause, regroup, and get those answers.

For more on building any startup on a solid foundation, avoiding common legal and regulatory mistakes, and fundraising successfully and legally, check out my book, Startup Law and Fundraising for Entrepreneurs and Startup Advisors (https://www.amazon.com/dp/0578236702), and my blog, www.StartupGC.us(http://www.startupgc.us/) . 